\title{
TUTORS' PERCEPTION ABOUT TEACHER TRAINEES' APPRAISAL OF TUTORS' PERFORMANCE AS PART OF QUALITY TEACHING AND LEARNING IN THE COLLEGES OF EDUCATION IN GHANA
}

\author{
Bliss Cornelius Sedega', Mark Mishiwo', Bridget Aku Dorkenoo', Frederick Kwasi \\ Togah $^{2}$, Benedicta Mawuse Danku' ${ }^{1}$ and Joshua Deku${ }^{1}$ \\ ${ }^{1}$ Akatsi College of Education, Ghana \\ ${ }^{2}$ Dambai College of Education, Ghana
}

\begin{abstract}
The study intended to explore the perception of the college tutors about the performance appraisal of tutors by the student teachers as part of quality teaching and learning in the Colleges of Education in Ghana as well as improving the tutors' performance and development. . Sixty seven (67) tutors were randomly selected from three Colleges of Education to constitute the sample for the study. A questionnaire was used to collect data for the study. The study found that college tutors generally acknowledged the relevance of performance appraisal to their job goals and development. Secondly, college tutors perceived performance appraisal feedback as irregular and unconstructive and did not reflect their actual performance. Thirdly, college tutors perceived the performance appraisal processes as being unfair because they were left out in the discussion of the assessment procedures claiming that performance appraisal by the student teachers alone is not enough, Fourthly, college tutors perceived that the student teachers judgment were affected by hallo and horn effect. Last but not least, college tutors somehow did not take their performance appraisal by the student teachers alone very seriously. It was recommended that assessment procedures and items leading to appraising the performance of the college tutors should be discussed with them to enable them state their positions openly in order to satisfy their needs. Also, there should be the need for triangulation of the assessment processes leading to appraising the performance of the college tutors to ensure checks and balances as well as validity of the results. Finally, performance appraisal feedback should be made regular, constructive, fair and useful to enable college tutors receive and support the programme as genuinely helping them to improve their performance and development.
\end{abstract}

KEY WORDS: perception, appraisal, performance, quality, teaching and learning.

\section{INTRODUCTION}

Educational institutions including schools the world over are currently facing the greatest challenge in providing quality education and to be accountable to their clients and communities (Darling-Hammond \& Richardson, 2009). It has become increasingly clear that the quality of teacher education is among the most important factors shaping the learning and growth of 
students (Darling-Hammond \& Bransford, 2006; Goodwin, 2008).To achieve quality education, teacher performance appraisals are parameters to evaluate teachers' performance against set standards (Dessler, 2003).

Researchers and practitioners have been interested in measuring human performance for a long time. Therefore, most educational planners and policy makers have made the management of teachers' performance appraisals (PA) critical core business for teachers' professional development (Miller, 2009). Performance appraisal more broadly defines "activities through which organizations seek to assess employees and develop their competence, enhance performance and distribute rewards (Fletcher, 2001). Performance appraisal (PA) was introduced in the United States of America in the 1940s during the Second World War as a method of justifying employees' wages (Moorhead \& Graffin, 1992). It was then known as merit rating. The merit rating was based on material outcome where higher output was rewarded with higher pay and vice-versa. Concerning appraisal process, Scullen, Mount and Judge (2003) noted that the appraisal process has been categorized into establishing job criteria and appraisal standards, timing of appraisal, selection of appraisers and providing feedback. Gurbuz and Dikmenli ( 2007) observed that various applications of performance appraisal have left many managers in a state of confusion and frustration with the employee evaluation process.

Maravec ( 1996) observed that teachers are opposed to the use of the appraisal form and advocated for an evaluation mechanism that are more interactive, inclusive and emphasizing on teams, values, employees' job roles and customer needs. According to Santiago, Roseveare, van Amelsvoort, Manzi and Matthews (2009), the reason that teachers play a central role in the delivery of quality education, makes it imperative that they are well monitored and they receive quality training so that they are able to deliver a service of the highest standard. A popular justification for focusing on the performance appraisal of teachers is that teacher appraisal has the potential to improve the teaching profession and the effectiveness of teachers (Verspoor, 2008 ). Meanwhile, one of the main factors that have been found to influence the outcomes of performance appraisal is the perception that teachers have about the appraisal system (Monyatsi, Steyn \& Kamper, 2006). Besides, Peterson (2000) identified that teacher appraisal process often faces problems associated with the negative perceptions of teachers towards the appraisal system.

Colleges of Education in Ghana now pay more and more attention on adopting quality assurance mechanism as well as systems in order to ensure that quality teachers are produced, hence, the need to put policies in place to enhance human resource and institutional performance (T-TEL, 2016). Performance appraisals are one of the most important requirements for successful institutional and human resource policy (Kressler, 2003). The human resource system can become more effective by having a valid and accurate appraisal 
system used for rating performances of employees (Armstrong, 2006). London (2003) identified that performance appraisals can be conducted effectively if there is a fair and accurate assessment of an employee's performance. According to London (2003), the evaluation of an employee's performance is a difficult task and opined that once the supervisor understands the nature of the job and the sources of information, the information needs to be collected in a systematic way, provided as feedback, and integrated into the institution's performance management process for use in making compensation, job placement, and training decisions and assignments.

According to Malongwe (2005) supervisors and appraisees have different needs and expectations regarding the appraisal exercise but the supervisor's purpose, intentions and perceptions of the appraisal process may differ significantly from those of the appraisees. The only complaint according to Bersin (2008), from employees was that the PA process was not equitable and fair since the process concentrated much in assessing past behaviours of employees, a situation some managers exploit to victimize unfavoured employees. Armstrong (2006) also identified that performance appraisal too often degenerated into a dishonest annual ritual where the education sector has not been spared either. Meanwhile, Malongwe (2005) observed that employees react more favourably to performance appraisal when it satisfies their needs and include an opportunity to state their position, when factors on which they are being evaluated are job related and the objectives and plans of the evaluation are discussed openly. In the context of the school system, the thrust of the PA system is to identify specific needs of teachers, provide support for continued growth, promote accountability, monitoring the school' $\mathrm{s}$ overall effectiveness and evaluate teachers' performance (Santiago et al. 2009). Perceptions of employees about the targets, outcomes and uses of performance appraisal (PA) results would be beneficial depending on a number of factors. For example, employees are more likely to be receptive and supportive of a given PA programme if they perceive the process as a useful source of feedback which helps to improve their performance (Mullins, 2007). Employees are likely to embrace and contribute meaningfully to a given PA scheme if they perceive it as an opportunity for promotion, and as an avenue for personal development opportunities, a chance to be visible and demonstrate skills and abilities, and an opportunity to network with others in the organization. According to Thurston and McNall (2010), performance appraisal and its outcome play a key role in employees ${ }^{e e}$ job activities and the organization, hence, it is vital to conduct a study on how tutors perceive performance appraisal. However, Armstrong (2006) noted that performance appraisal has been operated frequently as a top-down and largely bureaucratic system owned by the Human Resource (HR) department rather than by line managers. Also, performance appraisal tend to be backward looking, concentrating on what had gone wrong rather than looking forward to future development needs. Further, performance appraisals existed in isolation as there was little or no link between them and the needs of the organization. Employees have resented the superficial nature with which appraisals have 
been conducted by managers who lacked the required skills and tend to be biased. Danku, Soglo, Dordor and Bokor ( 2015) revealed in their study some of the perceptions towards performance appraisal by examining the perception of teachers regarding performance appraisal systems (PAS) in the Ghana Education Service. Even though performance appraisal seemed to achieve the desired results elsewhere, that has not been the case in Ghana as indicated by Danku, Soglo, Dordor and Bokor ( 2015) who identified that appraisal and performance management in Ghanaian educational institutions have had limited and confused purposes and their contribution to enhance institutional performance and quality has been minimal. However, no study in Ghana has particularly looked at how tutors perceive performance appraisal introduced in the colleges of education as a mechanism for ensuring quality in teaching and learning, hence enhancing the performance and development of the tutors. The study therefore, sought to explore tutors' perception of performance appraisal made by teacher trainees about the quality of teaching and learning in the Colleges of Education in Ghana.

\section{Purpose of the Study}

The study intended to explore the perception of the college tutors about the performance appraisal of tutors by the student teachers as part of quality teaching and learning in the Colleges of Education in Ghana as well as improving the tutors' performance and development.

\section{Research Questions}

1. What is the perception of the college tutors about the relevance of performance appraisal of tutors by the student teachers?

2. How do the college tutors perceive the feedback of their performance appraisal by the student teachers?

3. What is the perception of the college tutors about the fairness of performance appraisal processes?

4. To what extent do hallo and horn effect affect the judgment of the student teachers during performance appraisal?

5. What is the attitude of the college tutors towards the performance appraisal of tutors by the student teachers?

\section{Significance of the Study}

The results of the study will provide researchers with various forms of data for future studies. The results may also inform the evaluation of professional development sessions for the college tutors as well as the review of the performance appraisal programme. 


\section{LITERATURE REVIEW}

\section{Relevance of appraisal system}

About the importance of performance appraisal to career goals, Boachie-Mensah and Seidu (2012) indicated that about $44 \%$ of the respondents held the view that performance appraisal was important to their individual career goals and development. Additionally, nearly $18 \%$ of them were of the view that performance appraisal was highly important to their career objectives and ambitions. In contrast, about $11 \%$ were of the opinion that PA was highly unimportant or simply unimportant to their respective career goals, while about $27 \%$ indicated that it was somewhat important to their career objectives. The $11 \%$ who thought performance appraisal was unimportant to their career goals contended that appraisal in the institution was just a formality, and therefore a waste of time.

Danku, Soglo, Dordor and Bokor (2015) also found that over 50\% of respondents consider the appraisal process as a waste of time as they could not relate the appraisal process to their personal development. About $46 \%$ of the respondents held the view that performance appraisal was important to achieving the goals of the institution. About $31 \%$ of them believed it was highly important to appraise the performance of employees as part of the process of attaining success in the institution. About $14 \%$ indicated that performance appraisal was somewhat important to the success of the institution, while a minority (about 8\%) maintained it was highly unimportant or simply unimportant to achieving the goals of the institution.

Asiago and Gathi (2014) found out $69.7 \%$ of teachers considered the performance appraisal ineffective in determining the in-service training courses of teachers. $19.2 \%$ found performance appraisal results less effective while $10.1 \%$ had no opinion.

\section{Feedback of appraisal system}

It was found out in their study (Danku, Soglo, Dordor and Bokor,2015) that $75 \%$ of the respondents indicated that they were given feedback after appraisal programmes but conceded that it was irregular and unconstructive. The remaining $25 \%$ suggested otherwise indicating that they were not provided any feedback at all. In addition, $70 \%$ of respondents did not believe that feedback reflects their performance and questioned the need for the appraisal process. It came to light that over $50 \%$ of respondents considered the appraisal process as a waste of time as they could not relate the appraisal process to their individual performance.

\section{Fairness of performance appraisal system}

According to Martin and Bartol (2003), the fairness perceptions about various components of performance appraisal have very serious implications not only for employees, but also for an organization. In the context of performance appraisal, variables pertaining to fairness included knowledgeable supervisor, chance given to employee for expressing his/her appraisal related feelings and appraisal frequency in a rating year. Adams (1965) cited in Danku, 
Soglo, Dordor and Bokor ( 2015) reported that employees' perceptions of fairness depend on one or more of their perceptions concerning the various organizational outcomes which they received from the organization (distributive justice), procedures used to make those decisions (procedural justice) and the treatment which they received from the organization (interpersonal justice) and all the required information related to various outcomes is provided within an organization (informational justice). Danku, Soglo, Dordor and Bokor (2015) sought on teachers perception on the orientation of fairness of performance appraisal programmes and found out that only 20 respondents $(11.1 \%)$ believed that performance appraisal process was undertaken in fairness with the remaining $88.9 \%$ (160 respondents) who felt the process was unfair arguing that it was used to victimize some staff members.

\section{Hallo and Horn Effect of Appraisal System}

One of the most common errors in performance appraisal is the halo effect which influenced a rater's general impression on ratings of specific ratee qualities (Solomonson \& Lance,1997). The rater could give subordinates good grades although their performances were not worthy. Sometimes one prominent characteristic of the subordinate may colour the supervisor's perception of other qualities of the subordinate. Boachie-Mensah and Seidu (2012) found in their study that approximately $42 \%$ of the respondents perceived that some of the raters had the tendency to view positively all behaviour of subordinates because the rater liked a particular behaviour of the subordinate. Meanwhile, about 79.3\% of them believed that some or most or all raters manifested halo effect during appraisal. Nearly $35 \%$ of them also thought most of the raters committed this error, while almost $3 \%$ claimed all of the raters committed it.

Horn effect is the opposite of halo effect. It means that the rater might give poor grade even though the ratee's performance is commendable. According to Lefkowitz (2000) some raters have tendencies to view negatively all behaviour or actions of a subordinate because the superior dislikes a particular behaviour or action of the subordinate. Similarly, BoachieMensah and Seidu (2012) identified that $39 \%$ of the respondents were of the view that some of the raters had the tendency to consider negatively all behaviour of a subordinate, because the rater disliked a particular behaviour of the subordinate. Approximately $32 \%$ of them believed that most of the raters committed horn effect during appraisal. Meanwhile, about $4 \%$ of them claimed all the raters committed the error.

\section{Attitude towards appraisal system}

Odhiambo (2003) and Richus (2007) carried out a study on the experience of teachers appraisal practices and found that teachers had a negative perception towards performance appraisal. Asiago and Gathi (2014) conducted a study on teachers' perceptions of performance appraisal practices which revealed that teachers have a negative attitude towards performance appraisal practices used to appraise them. Regarding whether teachers were aware of the significance 
of performance appraisals in the teaching profession, $53.2 \%$ of the teachers indicated that they were not aware of the significance of the performance appraisal since their supervisors often used immediate supervisor performance appraisal approach which made teachers have no or little say in the performance appraisal.Danku, Soglo, Dordor and Bokor (2015) found in their study found out that $71 \%$ of respondents were of the opinion that some supervisors only use performance appraisal as an opportunity to victimize them.

\section{Perception of the recency error}

Boachie-Mensah and Seidu (2012) found that $45 \%$ of the respondents believed some of the raters were influenced by some subordinates' frequent display of behaviour that they (raters) liked when appraisal time was approaching. Also, about $17.1 \%$ of them held the view that most of the raters committed this error when appraising subordinates whom they had insufficient information on their overall work-performance. However, $17.9 \%$ of them believed none of the raters in the institution committed the recency error.

\section{Perception of the Error of Strictness}

Boachie-Mensah and Seidu (2012) indicated in their study that $44 \%$ of the respondents perceived that some of the raters had very high rating standards. Almost $18 \%$ of them claimed that most of the raters were the strict type who had the tendency to give low ratings even though the employee's performance might be relatively commendable. Meanwhile, 27\% of them were of the view that none of the raters displayed such tendency.

\section{Perception of the Leniency Error}

It was found out that $42 \%$ of the respondents perceived that some of the appraisers had the tendency to give unusually high ratings to all ratees unless they (ratees) had a clear deficiency, or they (raters) might not want to adversely impact the future of subordinates. Majority (58\%) of the respondents perceived that some or most or all raters committed lenient errors when rating (Boachie-Mensah \& Seidu, 2012).

\section{Perception of the Similarity Effect}

Boachie-Mensah and Seidu (2012) study found out that approximately $41 \%$ of the respondents believed some raters gave better rating to those subordinates similar to them (raters) in terms of behaviour, personality, or background. About 34\% of them thought that most of the raters committed the similar-to-me error during appraisal, while 5\% claimed all raters committed it. The similarity effect was probably the most common appraisal bias with nearly $81 \%$ of them perceiving that some or most or all raters manifested this bias 


\section{Theoretical Perspective}

The study is informed by the goal-setting theory as developed by Edwin Locke. In terms of this theory, the goal is the aim of an action or a task that a person consciously desires to achieve or obtain (Locke \& Lathan, 2002). The goal- setting theory starts from the simple observation that setting performance goals for employees motivates them to strive towards achieving these goals (O’Neil \& Drillings, 1994). In this way, an assigned goal influences employees' beliefs about being able to perform the task at hand and if it becomes certain that current performance is not achieving desired goals, employees would be motivated to increase effort or change their strategy (Schultz, 2006). This theory is relevant to this study because the performance management system is among other things a process of setting specific performance goals for the employee which in turn serves as a potent motivating force for them. Regarding this model, the goals and standards of the colleges were designed in line with the vision of the colleges which is disseminated through the members of staff.

\section{METHODOLOGY}

\section{Research Design}

The research made use of descriptive survey. This type of research would assist to describe the characteristics that exist in population, but not to determine the cause-and- effect relationship. The justification for the use of the design was that it provided detailed description of tutors' perceptions of the appraisal of their performance by the student teachers as part of quality teaching and learning in the colleges of education in Ghana.

\section{Population}

The population consisted of all tutors teaching at the Colleges of Education in Ghana.

\section{Sample and Sampling Technique}

Three colleges of Education were selected from the Volta and Oti regions of Ghana for the study. Akatsi College of Education located in the Volta region of Ghana was purposefully selected for the study because that was the college where majority the researchers were teaching thus, the tutors were easily accessible. St. Francis College of Education also located in the Volta region of Ghana and Dambai College of Education located in the Oti region of Ghana were randomly selected for the study. Sixty seven (67) tutors were randomly selected from these three Colleges of Education to constitute the sample for the study. Twenty seven (27) tutors from Akatsi College of Education and twenty (20) tutors each from St. Francis and Dambai Colleges of Education.

\section{Instrument}

A questionnaire was used to collect data for the study. The questionnaire was structured into five main sections that is, relevance of performance appraisal, feedback on performance appraisal, fairness of performance appraisal, tutors' attitude towards performance appraisal and the effect of hallo and horn on performance appraisal. Respondents were asked to indicate their 
British Journal of Education

Vol.8, Issue 4, pp.1-16, April 2020

Published by ECRTD- $U K$

Print ISSN: ISSN 2054-6351

Online ISSN: ISSN 2054-636X

levels of agreement with the various items under each section on a four-point scale $(1=$ strongly disagree, 2 = disagree, 3 =agree, $4=$ strongly agree). The scores were interpreted as follows: one is the lowest possible score which represents a negative perception, while four is the highest possible score which represent a very strong positive perception.

\section{Data Collection Procedure}

The researchers visited the colleges and administered the questionnaires to the tutors having explained the purpose of the study and the sampling techniques. The respondents were given enough time to complete the questionnaire. All retrieved questionnaires were adequately completed and were found usable for the study.

\section{Data Analysis}

The data collected were organized and analyzed using statistical tools such as mean, standard deviation and skewness.

\section{RESULTS}

Research Question 1: What is the perception of the college tutors about the relevance of performance appraisal of tutors by the student teachers?

Research Question 1 intended to solicit the views of the respondents about the relevance of performance appraisal of tutors by the teacher trainees or whether performance appraisal of tutors by the teacher trainees is important to achieving the tutors' job goals and also the goals of the institution.

Table 1: College tutors' perception about the relevance of performance appraisal of tutors by the student teachers.

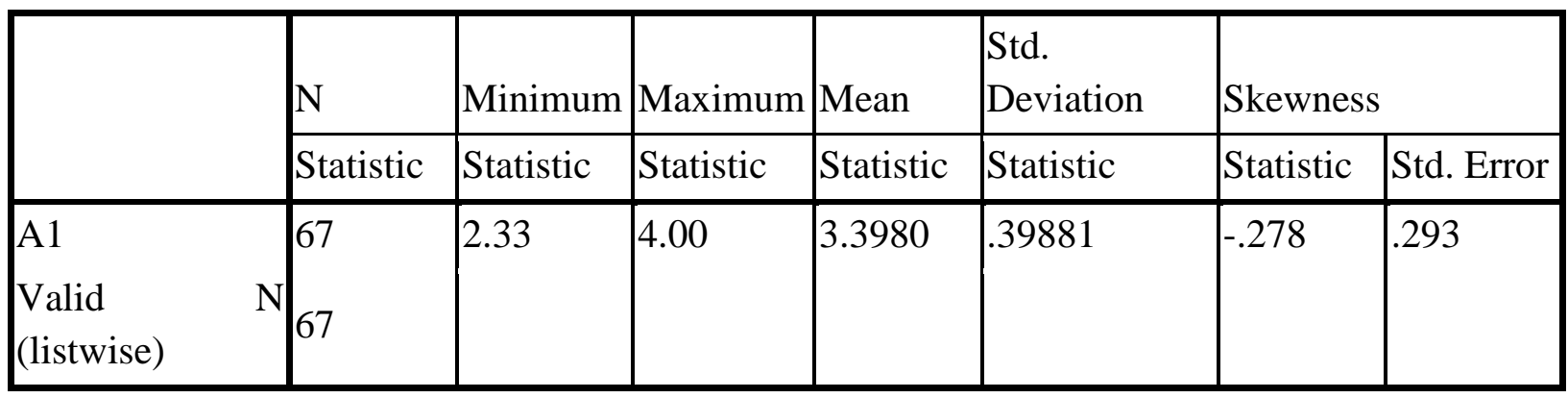

Table 1 indicated that college tutors perceived the performance appraisal of tutors by the student teachers in general as relevant and important in achieving the tutor's job goals and the overall goals of the institution. Tutors were also of the view that the performance appraisal of tutors by the student teachers could be effective in determining the relevant in-service training 
Vol.8, Issue 4, pp.1-16, April 2020

Published by ECRTD- $U K$

Print ISSN: ISSN 2054-6351

Online ISSN: ISSN 2054-636X

courses for them (mean $=3.398)$. A standard deviation of $(\mathrm{s}=.399)$ revealed that they do not differ in their perception about the probable relevance of performance appraisal. They held similar views that performance appraisal in general could be significant to the teaching profession, important to tutors' career goals and development, needs to be taken seriously and implemented in the colleges. A negative coefficient of skewness ( $\mathrm{Sk}=-.278$, not sig) revealed that the distribution is skewed to the left with the mean $<$ median $<$ mode also indicating the perception that performance appraisal could be relevant and usefulness to the career goals and development of tutors and the institution.

Research Question 2: How do the college tutors perceive the feedback of their performance appraisal by the student teachers?

Table 2: College Tutors perception about performance appraisal feedback.

\begin{tabular}{|c|c|c|c|c|c|c|c|}
\hline & $\mathrm{N}$ & Minimum & Maximum & Mean & $\begin{array}{l}\text { Std. } \\
\text { Deviation }\end{array}$ & Skewnes & \\
\hline & Statistic & Statistic & Statistic & Statistic & Statistic & Statistic & Std. Error \\
\hline \begin{tabular}{|l} 
A2 \\
Valid \\
(listwise)
\end{tabular} & $\begin{array}{l}67 \\
67\end{array}$ & 1.40 & 4.00 & 2.5552 & .39207 & .523 & .293 \\
\hline
\end{tabular}

Table 2 showed a positive coefficient of skewness ( $\mathrm{Sk}=.523$ ie sig.) which revealed that the distribution is skewed to the right with the mean > median > mode indicating a low perception which pointed to the case that performance appraisal feedback is irregular and unconstructive and did not reflect the actual performance of the tutors. A standard deviation of $(s=.392)$ indicated that tutors did not differ in their views that when feedback from performance appraisal is not provided on time, it makes the entire exercise a waste of time.

Research Question 3: What is the perception of the college tutors about the fairness of performance appraisal processes? 
Table 3: College Tutors' perception about the fairness of performance appraisal processes.

\begin{tabular}{|c|c|c|c|c|c|c|c|}
\hline & $\mathrm{N}$ & Minimum & Maximum & Mean & $\begin{array}{l}\text { Std. } \\
\text { Deviation }\end{array}$ & Skewnes & \\
\hline & Statistic & Statistic & Statistic & Statistic & Statistic & Statistic & Std. Error \\
\hline $\begin{array}{l}\text { A3 } \\
\text { Valid } \\
\text { (listwise) }\end{array}$ & $\begin{array}{l}67 \\
67\end{array}$ & 1.50 & 3.50 & 2.4975 & .45365 & .118 & .293 \\
\hline
\end{tabular}

Table 3 indicated that college tutors perceived the performance appraisal processes as being unfair. Tutors were of the view that the items in the performance appraisal package were not discussed with them before implementation and that they were not given the chance to comment on their evaluation scores. Tutors were again of the view that performance appraisal by the student teachers alone is not fair, that course by course analysis of the student teachers' performance at the end of every semester should also be considered a key factor for the fairness of the exercise, $($ mean $=2.498)$. A standard deviation of $(\mathrm{s}=.454)$ revealed that the tutors were unanimous in their views that performance appraisal processes are unfair. A positive coefficient of skewness ( $\mathrm{Sk}=.118$ ) revealed that the distribution is skewed to the right with the mean > median > mode also indicating that majority of the tutor held similar perception that performance appraisal processes are unfair because they were left out in the discussion of the assessment procedures among others.

Research Question 4: To what extent do hallo and horn effect affect the judgment of the student teachers during performance appraisal?

Table 4: Tutors' perception about the effect of hallo and horn on the judgment of the student teachers.

\begin{tabular}{|c|c|c|c|c|c|c|c|}
\hline & $\mathrm{N}$ & Minimum & Maximum & Mean & $\begin{array}{l}\text { Std. } \\
\text { Deviation }\end{array}$ & Skewnes & \\
\hline & Statistic & Statistic & Statistic & Statistic & Statistic & Statistic & Std. Error \\
\hline $\begin{array}{l}\text { A4 } \\
\text { Valid } \\
\text { (listwise) }\end{array}$ & 67 & 1.00 & 3.75 & 2.6269 & .56971 & -.893 & .293 \\
\hline
\end{tabular}

Table 4 revealed a negative coefficient of skewness ( $\mathrm{Sk}=-.893$ ie sig.) which showed that the distribution is skewed to the left with the mean < median < mode indicating a very high perception that hallo and horn effect significantly affected the judgment of the student teachers. 
Tutors were of the view that the student teachers are highly likely to view the behavior of a tutor positively or negatively because they like or dislike the tutor. A standard deviation of (s $=.570$ ) indicated that tutors were unanimous in their views that the student teachers have the tendency to victimize the strict type tutors by rating them poorly because they dislike them or be lenient with some tutors who influenced them with frequent display of behaviours that the student teachers liked.

Research Question 5: What is the attitude of the college tutors towards the performance appraisal of tutors by the student teachers?

Table 5: Attitude of tutors towards performance appraisal by the student teachers.

\begin{tabular}{|c|c|c|c|c|c|c|c|}
\hline & $\mathrm{N}$ & Minimum & Maximum & Mean & $\begin{array}{l}\text { Std. } \\
\text { Deviation }\end{array}$ & Skewnes & \\
\hline & Statistic & Statistic & Statistic & Statistic & Statistic & Statistic & Std. Error \\
\hline $\begin{array}{l}\text { A5 } \\
\text { Valid } \\
\text { (listwise) }\end{array}$ & $\begin{array}{l}67 \\
67\end{array}$ & 1.78 & 3.56 & 2.7114 & .38493 & .160 & .293 \\
\hline
\end{tabular}

Table 5 showed a positive coefficient of skewness ( $\mathrm{Sk}=.160$, not sig. though) which revealed that the distribution is skewed to the right with the mean $>$ median $>$ mode indicating a low attitude which pointed to the case that tutors were somehow not enthused about student teachers being the only judges or the only criteria to use when it comes to appraising their performance. A standard deviation of $(\mathrm{s}=.385)$ indicated that tutors did not differ in their attitudes that they somehow do not take seriously the exercise where student teachers are used as the only judges of their performance appraisal.

\section{DISCUSSION}

From Table 1, it was evident that about $85 \%$ of the college tutors perceived the performance appraisal of tutors by the student teachers in general as relevant and important in achieving the tutor's job goals in particular and the overall goals of the institution. This finding gave credence and solidified the study conducted by Boachie-Mensah and Seidu (2012) who indicated that about $44 \%$ of the respondents held the view that performance appraisal was important to their individual career goals and development. Again, our study also revealed from Table 1 that most of the college tutors (about 85\%) perceived that performance appraisal of tutors in general could be effective in determining the relevant in-service training courses for them. This finding was at variance with that of Asiago and Gathi (2014) who found out that $69.7 \%$ of teachers 
considered the performance appraisal ineffective in determining the in-service training courses of teachers.

It was also revealed from Table 2 that about $64 \%$ of the tutors perceived performance appraisal feedback as irregular and unconstructive and did not reflect the actual performance of the tutors. This finding was in line with that of Danku, Soglo, Dordor and Bokor (2015) who reported that $75 \%$ of their respondents conceded that feedback after appraisal programmes was irregular and unconstructive. Again, it was revealed from Table 2 that $64 \%$ of the respondents claimed that when feedback from performance appraisal is not provided on time, it makes the entire exercise a waste of time. This finding was also in agreement with that of Danku, Soglo, Dordor and Bokor (2015) who found out that over 50\% of their respondents considered the appraisal process as a waste of time as they could not relate the appraisal process to their individual performance.

From Table 3, it was shown that $71.4 \%$ of the tutors perceived the performance appraisal processes as being unfair because the assessment procedures were not discussed with them before implementation and that they were not given the chance to comment on their evaluation scores. In addition, the tutors claimed that performance appraisal by the student teachers alone is not fair, that course by course analysis of the student teachers' performance at the end of every semester should also be considered a key factor in assessing them. This finding supported the study of Danku, Soglo, Dordor and Bokor (2015) who found out that only 20 respondents ( $11.1 \%$ ) believed that performance appraisal process was undertaken in fairness with the remaining $88.9 \%$ (160 respondents) who felt the process was unfair arguing that it was used to victimize some staff members.

It was also revealed from Table 4 that $70 \%$ of the tutors perceived that hallo and horn effect affected the judgment of the student teachers. Student teachers were highly likely to view the behavior of a tutor positively or negatively because they like or dislike the tutor or they have the tendency to victimize the strict type tutors by rating them poorly because they dislike them or be lenient with some tutors who influenced them with frequent display of behaviours that the student teachers liked. This finding supported the study by Boachie-Mensah and Seidu (2012) who found in their study that approximately $79.3 \%$ of the respondents perceived that some or most or all raters manifested halo and horn effect during appraisal.

Last but not least, our study revealed from Table 5 that even though tutors generally acknowledged the relevance of performance appraisal to their career goals and development about $76.2 \%$ of them were somehow not enthused about student teachers being the only judges or the only criteria to use when it comes to appraising their performance and could not take that approach seriously. This finding consolidated the study conducted by Asiago and Gathi 
(2014) who reported that teachers have a negative attitude towards performance appraisal practices used to appraise them.

\section{CONCLUSIONS}

The evidence available from the findings of this study provided the basis for a number of conclusions to be made. Firstly, it was found that college tutors generally acknowledged the relevance of performance appraisal to their job goals and development. Secondly, college tutors perceived performance appraisal feedback as irregular and unconstructive and did not reflect their actual performance, rendering the exercise a waste of time. Thirdly, college tutors perceived the performance appraisal processes as being unfair because they were left out in the discussion of the assessment procedures claiming that performance appraisal by the student teachers alone is not enough, that course by course analysis of the student teachers' performance at the end of every semester should also be considered a key factor in assessing them. Fourthly, college tutors perceived that the student teachers judgment were affected by hallo and horn effect. Last but not least, it was concluded that college tutors somehow did not take their performance appraisal by the student teachers alone very seriously.

\section{Recommendations}

Based on our findings and conclusions, the following recommendations were made.

1. Assessment procedures and items leading to appraising the performance of the college tutors should be discussed with them to enable them state their positions openly in order to satisfy their needs.

2. There should be the need for triangulation of the assessment processes leading to appraising the performance of the college tutors to ensure checks and balances as well as validity of the results.

3. Performance appraisal feedback should be made regular, constructive, fair and useful to enable college tutors receive and support the programme as genuinely helping to improve their performance and development.

\section{Implications for Research}

The study intended to provide good insight into the perception of the college tutors about the performance appraisal of tutors by the student teachers introduced into the Colleges of Education in Ghana as part of quality teaching and learning as well as improving the tutors' performance and development. It also aimed at adding to the existing literature by serving as a firm base for future researchers who would like endeavour into this area. 


\section{REFERENCES}

Adams, J. S. (1965). Inequity in social exchange. In L. Berkowitz (Ed.), Advances in Experimental Social Psychology, 2, 267-299. New York: Academic Press.

Allais, S. M. (2009). Quality Assurance in Education. Issues in Education Policy Number 5. Braamfontein: Johannesburg. Center for Education Policy Development Publishers. Armstrong, M. (2006). A handbook of Human Resource management Practice. Kogan Page Ltd: United Kingdom.

Asiago, D., \& Gathi, A. (2014). Teachers' Perceptions of Performance Appraisal Practices in Public Secondary Schools. Retrieved June 30, 2016 from http://ijern.com/journal/April-2014/01.pdf.

Bersin, J. (2008). The business case for performance management systems: A handbook for human resource executives and managers. Bersin and Associates Research Reports, 10, 9-22.

Boachie-Mensah, F. O., \& Seidu, P. A. (2012). Employees' Perception of Performance Appraisal System, International Journal of Business and Management, 7, 73-88.

Boyd, N. M., \& Kyle, K. (2004). Expanding the view of performance appraisal by introducing social justice concerns. Administrative Theory \& Praxis, 26(3), 249-278

Bransford, J., \& Darling-Hammond, L. (2006). Preparing teachers for a changing world: What teachers should learn and be able to do. San Francisco, CA: Jossey-Bass.

Cleveland, J. N., Murphy, K. R., \& Williams, R. E. (1989). Multiple uses of performance appraisal: Prevalence and correlates. Journal of Applied Psychology, 74(1), 130-135.

Danku, L, S., Soglo, N. Y., Dordor, F., \& Bokor, M. J. (2015). Performance appraisal in the Ghana Education Service, International Journal for Managerial Studies and Research, 3, 117-133.

Darling-Hammond, L., \& Bransford, J. (2006) Preparing Teachers for a Changing World: What Teachers Should Learn and Be Able To Do, Jossey Bass, San Francisco.

Darling-Hammond L., \& Richardson, N. (2009). Teacher learning: What matters? Association for Supervision and Curriculum Development, 66(5), 47-53.

Dessler, G. (2003). Human Resource Management. London: Prentice Hall.

Fletcher, C. (2001). Performance Appraisal and Management: The Developing Research Agenda. Journal of Occupational and Organizational Psychology, 74, 473-487.

Gabris, G. T., \& Ihrke, D. M. (2001). Does performance appraisal contribute to heightened levels of employee burnout? The results of one study. Public Personnel Management, 30 (2), 157-172.

Goodwin, A. L. (2008) 'Defining teacher quality: Is consensus possible?' in Cochran-Smith, M., Feiman-Nemser, S., McIntyre, D.J. and Demers, K.E. (Eds): Handbook of Research on Teacher Education: Enduring Questions in Changing Contexts, Routledge, New York, pp.399-403.

Gurbuz, S., \& Dikmenli, O. (2007). Performance appraisal in public organizations: An empirical study. Magazine of Management Practice, 13(1), 108-138.

Grote, D. (1996). The complete guide to performance appraisal. New York: American Management Association.

Kressler, H. W. (2003). Motivate and Reward Performance Appraisal and Incentive system for Business Success. New York: Palgrave Mac-Millan. 
British Journal of Education

Vol.8, Issue 4, pp.1-16, April 2020

Published by ECRTD- $U K$

Print ISSN: ISSN 2054-6351

Online ISSN: ISSN 2054-636X

Lefkowitz, S. W. (2000). The role interpersonal affective regard in supervisory performance ratings: a literature review and proposed causal model. Journal of Occupational and Organizational Psychology, 73(1), 67-85.

Locke, E. A., \& Latham, G. P. (2002).Building a practically useful theory of goal setting and task motivation. American Psychologist, 57,705-717.

London, M. (2003).Job feedback: Giving, seeking and using feedback for performance improvement. Mahwah, NJ: Lawrence Erlbaum.

Malongwe, C. (2005). Towards an effective self-appraisal. Gaborone: Government printers.

Maravec, C. H. (1996). Advanced concepts research project, NASA.

Martin, D. C., \& Bartol, K. M. (2003). Factors influencing expatriate performance appraisal system success: An organizational perspective. Journal of International Management, $9(2), 115-132$.

Mok, K.H. (2005) 'Questing for internationalization of universities in Asia: critical reflections', Journal of Studies in International Education, 11, 433-454.

Monyatsi, P., Steyn, T., \& Kamper, G. (2006). Teacher Perceptions of the effectiveness teacher appraisal in Botswana. South African Journal of Education, 26(3), 427-441.

Moorhead, G. J., Griffin, R. N (1992). Organizations' Behaviour (3rd Ed). Boston: Houghton Mifflin Company.

Mullins, L. J. (2005). Management and organizational behaviour. London: Prentice Hall.

Odhiambo, G. D. (2003). Teacher Appraisal. The experience of Kenyan secondary schools teachers, Journal of education administration, 43, 402- 416.

O’Neil, J. R., \& Drillings, M. (1994). Motivation: Theory and Research. Hillsdale: Lawrence Erlbaum Associates.

Peterson, K. D. (2000). Teacher evaluation: A comprehensive guide to new directions and practices. Thousand Oaks, CA: Corwin Press.

Richus, A. (2007). A survey of Teachers Perception of Performance Appraisal Practices in Public Secondary Schools in Nakuru District. Unpublished MBA Thesis

Roberson, Q. M., \& Stewart, M. M. (2006). Understanding the motivational effects of procedural and informational justice in feedback processes. British Journal of Psychology, 97(3), 281-298

Santiago, P., Roseveare D., van Amelsvoort, G., Manzi, J., \& Matthews, P. (2009). Teacher Evaluation in Portugal. Retrieved July 12, 2016 from <http://www.OECD.org/portugal/43327186.pdf>

Scullen, S. E., Mount, M. K., \& Judge, T. A. (2003). Evidence of the construct validity of developmental ratings of managerial performance. Journal of Applied Psychology, 88(1), 50-66. http://dx.doi.org/10.1037/0021-9010.88.1.50

Shultz, D. (2006). Psychology and Work Today: An Introduction to Industrial and Organizational Psychology. Florida: Pearson Education International

Solomonson, A., L., \& Lance, C. E. (1997). Examination of the relationship between true halo and halo error in performance ratings. Journal of Academic Applied Psychology, 82 (5), 665-674.

Thurston, P. W., \& McNail, L. (2010). Justice Perception of Performance Appraisal Practices. Journal of Managerial Psychology, 25 (3), 201-228.

UNESCO (2008). EFA Global monitoring report. Education for all by 2015: Will we make it? New York: Oxford University Press

Verspoor, A. M. (2008). At the Crossroads: Choices for secondary Education in Subsaharan Africa. Washington, DC: World Bank. 